DIGITAL COMMONS
@ UNIVERSITY OF SOUTH FLORIDA

Volume 8

Issue 1 Spring 2018

\section{ABO: Interactive Journal for Women in the Arts, 1640-1830}

2018

\title{
Review of Edinburgh Lyceum Theatre Production of Hannah Cowley's The Belle's Stratagem
}

Tanya M. Caldwell

Georgia State University, tmcaldwell@gsu.edu

Follow this and additional works at: https://digitalcommons.usf.edu/abo

Part of the Dramatic Literature, Criticism and Theory Commons, Educational Methods Commons, Feminist, Gender, and Sexuality Studies Commons, and the Literature in English, British Isles Commons

\section{Recommended Citation}

Caldwell, Tanya M. (2018) "Review of Edinburgh Lyceum Theatre Production of Hannah Cowley's The Belle's Stratagem," ABO: Interactive Journal for Women in the Arts, 1640-1830: Vol.8: Iss.1, Article 3. https://doi.org/10.5038/2157-7129.8.1.1191

Available at: https://digitalcommons.usf.edu/abo/vol8/iss1/3

This Reviews is brought to you for free and open access by Digital Commons @ University of South Florida. It has been accepted for inclusion in ABO: Interactive Journal for Women in the Arts, 1640-1830 by an authorized administrator of Digital Commons @ University of South Florida. For more information, please contact digitalcommons@usf.edu. 


\title{
Review of Edinburgh Lyceum Theatre Production of Hannah Cowley's The Belle's Stratagem
}

\begin{abstract}
This article reviews the production of Hannah Cowley's The Belle's Stratagem directed by Tony Cownie and produced for the Lyceum Theatre in Edinburgh in February and March 2018. In setting the play in Edinburgh and placing emphasis on its women characters, Cownie underscores the universal and timeless relevance of Cowley's play as well as its performance versatility.
\end{abstract}

\section{Keywords}

Hannah Cowley, domestic comedy, \#metoo, marriage, sisterhood, native values

\section{Creative Commons License}

(c) (1) (8)

This work is licensed under a Creative Commons Attribution-Noncommercial 4.0 License 
The Belle's Stratagem by Hannah Cowley

Lyceum Theatre, Edinburgh, February-March 2018

Dir. Tony Cownie

Reviewed by Tanya Caldwell

Georgia State University

In the main plot of Hannah Cowley's The Belle's Stratagem (1780), Letitia Hardy, betrothed in childhood to the wealthy and attractive Doricourt who has been abroad on the Grand Tour as the play opens, determines to make him fall in love with her for her own sake. Cowley's two-fold purpose is to emphasize the value of the domestic amidst growing cosmopolitanism with its corrupting influences and to demonstrate the prominence of women's roles in public and private spheres. The Edinburgh Lyceum Theatre production of The Belle's Stratagem, directed by Tony Cownie (see fig. 1), delightfully conveys both messages to a twenty-first century local audience with its Edinburgh setting and powerful women characters.

With an informal semi-prologue familiar to contemporary audiences, the heroine begins by establishing that in order to make the play relevant the action takes place in eighteenth-century Edinburgh - to be specific, New Town Edinburgh as Robbie Burns's arrival causes excitement. This setting augments the play. The Edinburgh references and jokes heightened enjoyment for the audience the night I attended (press night) and arise repeatedly in the interviews with playgoers included on the Lyceum site.

In appealing to local playgoers by changing the setting from London to Edinburgh while retaining the main characters and plot points, Cownie also demonstrates, however, the universal and timeless relevance of Cowley's play. In a scene that Cownie omitted from what was already two and a half hours of running time, Cowley's auctioneer Silvertongue responds to a gentleman's question about what city a model before them represents by reflecting, "That I have not been able to discover; but call it Rome, Pekin[g], or London, 'tis still a City. You'll find in it the same jarring interests, the same passions, the same virtues, and the same vices, whatever the name" (2.2). References to David Garrick, David Hume, and the French Revolution contextualize and broaden Cowley's rollicking comedy - which comes across as more rollicking, in fact, on Cownie's stage than on the page. Yet the joke of a night on the town works for any place or period when Cownie's revelers sum up the post-masquerade chaos as "Just another Saturday night in Edinburgh!"

Letitia Hardy is the lynchpin of Cownie's production as it demonstrates the pertinence of Cowley's themes concerning the value of the domestic and the rural against expanding empire as well as the power women held in society. In the role, Angela Hardie owns the stage from her dissatisfaction with the paternally arranged nuptials through her feigned madness and master stratagem. As Letitia, Hardie is stunning as she appears masked, clad in a red tartan Highland gown with plaid back sash in order to capture Doricourt's - and the audience's - hearts in the climactic masquerade scene. She is even more charming 
when she subsequently woos everyone in the theatre by playing a native ballad on a full size harp, framed beneath a candle chandelier.

The ultimate point of Cowley's play is one that Doricourt must learn and which he summarizes for the audience at the end: the "innate" qualities of "British Ladies" make them superior to "foreign Graces." Cownie captures Cowley's sentiment in his presentation of traditional Scottish virtue and simultaneously embraces the Romantic flavor of the play: "A damsel with a dulcimer / In a vision once I saw" (37-38), Coleridge might equally have breathed of this moment.

Cowley has not received the attention for her pre-feminist portrayals of gender roles that her contemporary Mary Wollstonecraft has, but her plays compellingly demonstrate the multiple ways in which women increasingly shaped the public and private spaces they inhabited in the eighteenth century. Cownie's production literally stages the social power of women in Cowley's time and the vitality of her characters with the vibrant energy and electric costumes of major and supporting actresses from the opening to the closing roles. The play's minor characters, Mrs. Racket and Mrs. Ogle, in particular, are constant presences on stage in vital pink and orange dresses commenting on marriage and the misery of women's lot. Despite or perhaps because of their vulgarity, which Cownie plays up, their humor, wit, and encouragement both of Letitia's plot and the young country wife Lady Frances's defiance of her boorish husband Sir George powerfully carry this play forward 230 years into the \#metoo movement.

Equally compelling for the agency she assumes as she emerges from the downtrodden ranks of voiceless women, Kitty Willis, the prostitute, first entertains with her dull wittedness during the masquerade scene. She thus keeps the audience on edge as to whether she will be able to pull off her own plot, which involves substituting for the vulnerable Lady Frances, a would-be rape victim. The sympathy and humor she generates in her triumph brings the wrath of the entire cast on the villain and creates goodwill throughout the theatre.

Cownie's subplot further augments Cowley's sisterhood and the vitality of her women, while demonstrating the performance versatility of her drama. Lady Frances, in her brown dress and mousey demeanor, undergoes a transformation initially closer to that scripted by William Wycherley in The Country Wife (1674) for her ancestor Margery Pinchwife. Cownie's Sir George appears more of a nincompoop than Cowley's - and slightly cruel like his predecessor Pinchwife. Thanks to the main plot and the humor of the play, Cownie pulls off the sentimental resolution Cowley wrote for these characters.

The Lyceum production, as Cownie shaped it for a twenty-first century Edinburgh milieu, highlights above all the timelessness and versatility of Cowley's eighteenth-century domestic comedy. In his exuberant celebration of women and place, Cownie remains true to the spirit of Hannah Cowley's comedy and, in so doing, gives us a glimpse into what it was like to be in her theatres. 
As I took the train back to England afterwards, I witnessed again the timeless emotions Cowley portrays in an example of Sir George's jealousy of his wife. I listened to a couple quarreling in the seat opposite me. As the man refused to go to a concert in Glasgow in July that she suggested, the woman calmly replied, "Then I'll go by meself." "What, love, you'd go without us?" Her partner looked shocked and sulked. I chuckled to myself as I imagined the woman sweeping off with her friends, a contemporary Mrs. Ogle and Racket.

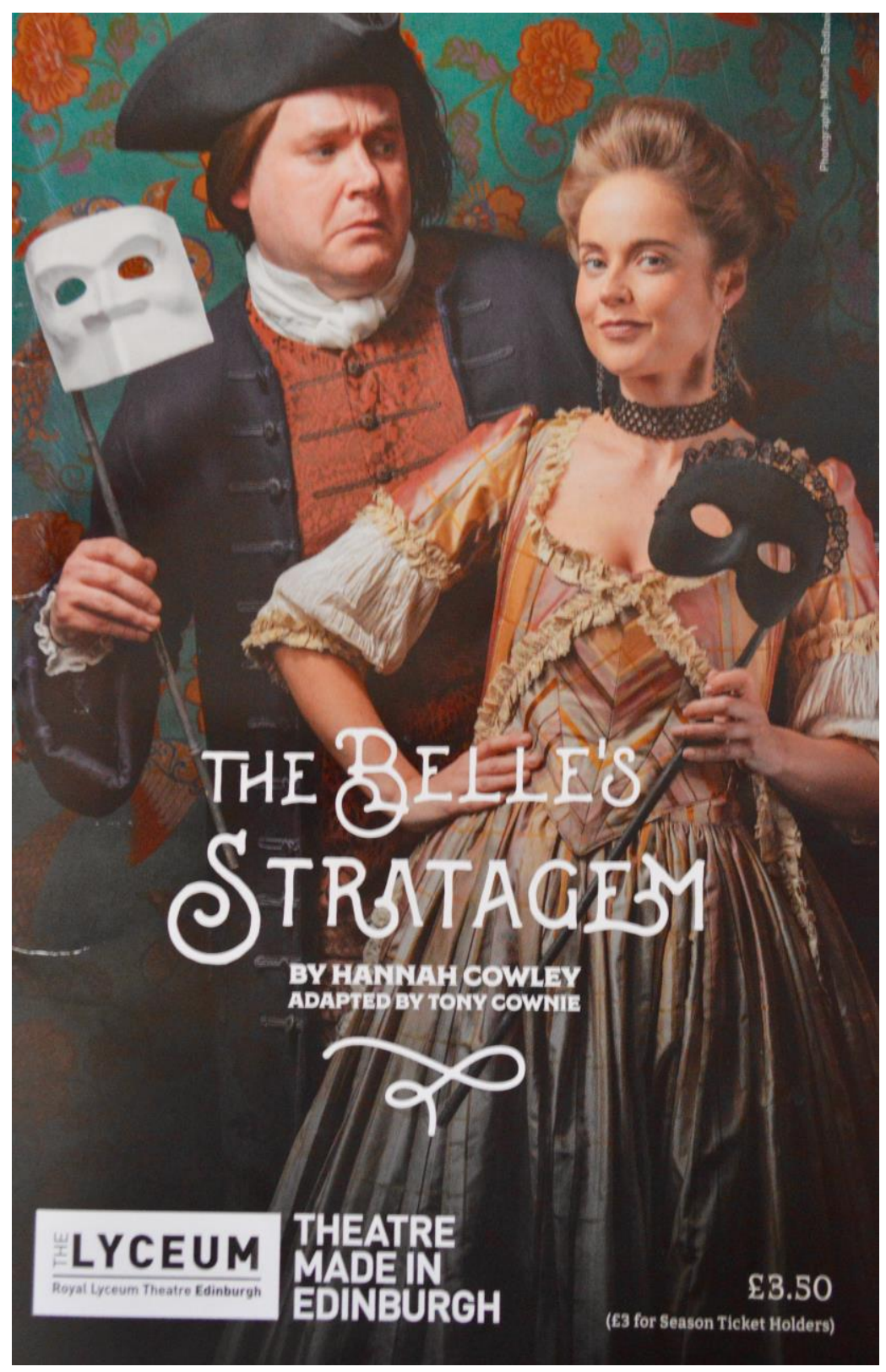

Fig. 1. Program cover for The Belle's Stratagem, directed by Tonie Cowie for the Royal Lyceum Theatre Edinburgh. 


\section{Works Cited}

Coleridge, Samuel Taylor. "Kubla Khan.” Samuel Taylor Coleridge: The Major Works, edited by H.J. Jackson, Oxford UP, pp. 102-03.

Cowley, Hannah. The Belle’s Stratagem. London, 1782. 